\title{
ヴェーダ文献における金属関連語
}

\section{山田智 輝}

0.はじめに ヴェーダ文献における金属全般についてはRau（1974）により， 既に子細な研究がなされている，本稿では，彼の研究を踏襲しつつも，その後の 諸研究がもたらした成果をも用い，同文献に打ける「卑金属類」に着目し，それ らの既知, 未知の段階, 並びに利用実態について, 文献毎に整理して概観する.

1. ヴェーダ文献における金属 金属類は「貴金属 (hiranya-)」と「卑金属 (áyas-)」の二種に大別される. hiranya-は本来は一義的に「貴金属」を意味した が, Atharvaveda (AV) 以降 hárita-híranya-「黄色い貴金属 $=$ 金」, rajatá- híranya「白く輝く色 (白銀色) の貴金属＝銀」と，色によって区別される ${ }^{1}$. AB VII 12,2 では, hiranya-が「金」, 本来形容詞であった rajatá-が「銀」として, それぞれ実 体詞として用いられる，「卑金属（áyas-)」についても同様に，AV 以降，色を表す 語が付加されて種類が区別される $(\rightarrow$ 4.).

2. RV における金属加工技術 金属加工に関わる記述は RV の段階から散見 される，RVX 72,2 に言及される動詞 sam-dhma につつて，後藤 (2004, 417f., 428f.) は, Junko Sakamoto-Goto が論じた Pāli 語における同語の事例を手がかりに,「溶 融する」と訳し，一連の行程中の「靽（díti-「革袋」を用いる）で吹く」という最初 の特徵的行程を意味する $d h m \bar{a} 「$ 吹く, 吹きかける, 風を送る」によって, 後続す る作業工程全体（䩴を使って風を吹きかけて，坩堝の中で原材料を溶かし合わせる，完全 に溶融する）を表す語法の一種と指摘する，RV の段階で既に金属生成の基本的行 程が知られていたことが暗示される：RV X 72,2 bráhmanas pátir etá | sám karmára ivādhamat |『ブラフマンの主がこれらを，鍛治屋が，のように，溶融した.』2)

3. karmārá-「鍛治屋」上の例にも現れた kārmārá-が,「鍛治屋」を意味する 一般名詞である。ヴェーダ文献中に全 13 回，5種の用例を有する。散文には事実 上用例が無い. 鍛冶屋達の素性を具体的に描く用例は見出されないが, 複数の用 例において, 戦車職人 (rathakārá-) や陶工（kúlāla-）等の，様々な技術者・専門職 
の者と並置されること, AV Śaunaka 派（AVŚ） III 5,6 Paippalāda 派（AVP） III

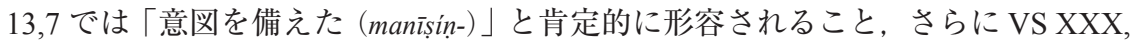
$7 \sim$ TB III 4,3,3 で「計算力 ( $m \bar{a} y \bar{a}-$, 高度な技術力 $\left.)\rfloor^{3}\right)$ と関連づけられることに着目 すれば，彼らはインド・アーリヤの伝統外に位置しながらも4), 高い技術力を有 する者達として相応の地位を得ていたものと推測される。 Jātaka III 281 では, ブ ラフマダッタ王によるバーラーナシ治世時に, カーシ国に 1000 もの小屋からなる 鍛治屋の村（sahassakutika- kammāragāma-）があり，鍛治屋達の最長者が王の龍愛を 受け，巨財を有していたことが述べられる。この記述は，往時の鍛治屋のイメー ジを補完する用例の一つに位置付けられるかもしれない.

4. áyas- RV において, 卑金属類はáyas-のみが登場する. Rau（1974, 19-24） は, 銅が唯一の卑金属として，貴金属に対置されている段階と指摘する.「卑金属 製の防御柵（产yasī- púr-）」（RV I 58,8 他）や「金属を牙に持つ（áyodamsțtra-）［Agni]」 （RV X 87,2）といった言葉によって代表されるように，「堅固さ」や「鋭さ」を象 徵する語として頻繁に用いられる。この観念は後代にも受け継がれる.

$\mathrm{AV}, \mathrm{YS}^{\mathrm{m}}$ の段階になると, áyas- という語に「黒い (śyāmá-)」乃至「赤い (lóhita-)」 という形容詞が付加され，卑金属類が色分けされる．前者は恐らく「鉄」を，後 者は「銅」をそれぞれ指す。また，trápu-「錫」(AV+), sís $a-\lceil$ 鉛」(AV+) といっ た，他の卑金属についても言及が現れる.AVŚ XI 3,7〜AVP XVI 53,12 はその一例 である. $\mathrm{YS}^{\mathrm{m}}$ においても同様の傾向が見出されるが, 金属名が列挙される一節に て, MS II 11,5: 142,5-7 ${ }^{\mathrm{m}} \sim$ KS XVIII 10: 272,8-10 ${ }^{\mathrm{m}} \sim \operatorname{KpS}$ XXVIII 10: 147,10-11 が lohitāyasá-「赤い卑金属（銅）」の語を用いる一方，それらに対応するVS 18,13～ TS IV 7,5,1 は, lohá-「銅」の語を用いる (同語の初出).

黒 YS ${ }^{p}$ では，金属の特性を伝える用例が見出される．以下は agnihotra で献供す

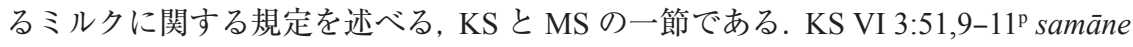
vai yonā āstām̆ sūryaś cāgniś ca. tatas sūrya ūrdhva udadravat. tasya retah parāpatat. tad agnir yoninopāgrhṇāt ayasā. tad akrūḍyat. tat krūḍyamānam gavi nyadadhāt. tad idam payas. tasmād atrapv ${ }^{+}$ayahpātram ${ }^{5)}$ pratidhuk krūdayati. 『共通の母胎に太陽と Agni は居たのだ.そこから，太陽は上方に走り出た，彼の精子は離れ落ちた。 そ れを Agni は母胎によって捕捉した, 卑金属 (áyas-) によって. それ（母胎／卑金 属）は［精子を］然やした ${ }^{6)}$ 。その然やされつつあるもの（精子）を，雌牛の中に 置き定めた，それがこの（今ここにある）ミルクである，それ故，錫を含まない， 卑金属 (áyas-) の器は搾りたてのミルクを燃やす.』〜 MS I 8,2:117,12-15 sahá vá 
etầ āstām agniś ca súrryaś ca samāné yónā áyasi lóhite. sá ādityá ūrdhvá údadravat. tásya rétạh párāpatat. tád agnír yóninópāgrhṇāt. tád enam̌ vyàdahat. tásmād áyo 'trapú pratidhúk kșīrám vídahati. 『これら Agni と太陽の両者は, 一緒に, 共通の母胎の中 にあったのだ，赤い卑金属の中に，そこで，Āditya は上方に走り出た．彼の精子 は離れ落ちた，それを Agni は母胎によって捕捉した。 それ（n. 精子）はそれ (m. 母胎）を焼き尽くした7)、それ故，錫を含まない卑金属は／を，絞られたばかりの ミルクを/は焼き尽くす ${ }^{8)}$.』KS と MS の記述を整理すると，KS では「卑金属 (áyas-) 」が「錫を含まない, 卑金属の器 (atrapu- ayahpātra-) 」9）と, MS では「赤い 卑金属 (áyas-lóhita-)」が「錫を含まない卑金属 (áyas-atrapú-)」と，それぞれ言い 換えられる，いずれも純銅を指すものと考えられる。また，KS，MS 共に「太陽 の精子」が「搾りたてのミルク」と，「Agni が居る母胎」が「火に掛けられた純 銅の器」とそれぞれ同一視される，両者の内容を総合すると，上の説話は，「純銅 の熱伝導率の高さ」を特に述べるものと解釈できる ${ }^{10)}$.

ŚB では, lohá-と áyas-が対比的に用いられる．また, áyas-が，色を表す形容 詞を伴わずに用いられる一方, lohá-の「赤い」という側面が明確に打ち出され る.この段階では, áyas- が「鉄」の意に定着しつつある可能性が指摘できる： ŚB V 4,1,2 . . nàitad áyo ná híranyam yál lohāyasám . . átha yál lohāyasám bhávati.

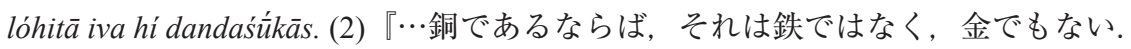
‥ささ，銅が用いられることについて，咬むもの（蛇？）はまさに赤いから.』さ らに次の用例は, áyas-（鉄）が, hiranya-（金) やlohá-（銅）よりも融点が高いこ とを伝える：ŚB XIV 2,2,54 sá yád vānaspatyáh syất prádahyeta. yád dhiranmáyah syát prálīyeta. yál lohamáyah syất prásicyeta. yád ayasmáyah syất prádahet parīsasasấv. áthaișá evàitásmā atișthata. tásmād etám mrnmáyenaivá juhoti. 『木製であるならば, それ（mahāvira 容器）は燃やされるだろう。金製であるならば，［それは］溶ける だろう、銅製であるならば，[それは］注ぎ出されるだろう ${ }^{11)}$ ，鉄製であるなら ば，［それは］二本の挟み棒を燃やすだろう。ささて，それ（gharma）はそれ（土製 の mahāvīra) に対して不動だった ${ }^{12)}$. それ故，これを土製のものによって献供する.』

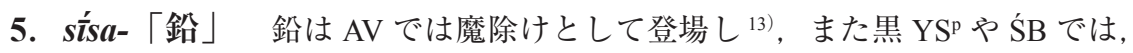
特に「宦官」や「髪の長い男」14) と何かを交換する際の交易品として頻繁に登場 する. áyas- とは異なり「鉛製の」等の表現は見出されない：MS II 4,2:39,4-6p sísena

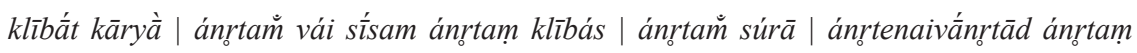

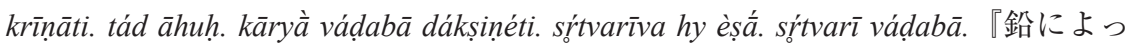


て，宦官から [surāを] 買うべきである ${ }^{15)}$. 鉛は虚偽なのだ。宦官は虚偽なのだ。 surā は虚偽なのだ。他ならぬ虚偽によって，虚偽から，虚偽を買う。そこで人々 は言っている.「雌馬／騾馬（？）16）を布施とするべきである」と。このもの（surā) は素早いから. 雌馬／騾馬（？）素早いから.』17)

6. その他 trápu-「錫」(AV+) は, 本稿中に挙げたもので全用例を網羅する. $k a \dot{m} s a ́-\lceil$ 金属器」(AV+) > kāmsya-「kamsa 製の」( $\operatorname{SrSu}+)$ という，製品名が金属 名に先立つ例については EWAia I, 285f. に解説（先行研究紹介を含む）を譲る.

7.まとめ RVの段階では, 卑金属にはáyas-という語のみが用いられ, 種類は 区別されない. AV の段階で, áyas-が「黒」と「赤」の二色に分けられ，また， 錫，鉛といった他の金属についても言及される，YS VS と TS は, lohá-「銅」という語を伝える，YSp では，純銅の特性を伝える用例 が見出される. ŚBでは, áyas-の色分けがなされず，部分的に同語が「鉄」を限 定的に指すと判断できる用例が現れる.

1) Cf. Rau (1974, 18-19).

2） RV X 81,3 には「翼（pátatra-）たち（送風用の道具）」 を用いた溶融 (sam-dhmā) の例がある．RV V 9,5 では dhmátar-「吹き手」が「鍛治屋」 の意で用いられる.

3) Cf. Gotō, $W G-R V I, 838$.

5) Cf. Mittwede $(1989,51) . \mathrm{KS}\langle$ Ed. Schroeder $\rangle$ : atrapvayah pātram.

については Kulikov（2012,465-467）が研究史も含め, 簡潔に解説する. 当語は「厚くす る」，「凝固する」等と訳されてきたが, Kuiper $(1991,75 f$.) は, それらの訳語は伝統的解 釈に拠る $P W$ の語義（EWAia I, 415 もこれを登録する）に基づく誤解釈として批判し, 他 の並行箇所の言及との整合性にも鑑み,「燃やす, 加熱する」と訳すべきと指摘する. Kulikov（2012）は Bodewitz (1976,34f.) の「stick (burn) (to the iron pan)」という訳を，蓋 然性の高いものとして紹介する.

7）後続する文では, ミルクは加熱しすぎても (átiśrta-), 非加熱でも（ássrta-）献供には適さず，容器の縁まで完全に沸き上がった (samúdanta-) ものを用いるべきことが述べられる. よって, 燃やされるものはミルク（= 太陽の精子）と予測されるが, この一文のみ, その解釈を許さない. 次注も参照.

8) Rau (1974, 20): "Der [d.h. der Samen] verdarb ihn [d.h. den Mutterschoß] durch Hitze. Daher verdirbt Nutzmetall Kupfer ohne Zinn[-beimischung] frishce Milch durch Hitze.” Amano (2009, 284): "er (der Same) verbrannte ihn (den Mutterschoß); deswegen verbrennt die gerade gemolkene, frische Milch Nutzmetall (Kupfer) ohne Zinn[-beimischung].” 所の áyas- が特に銅を指す可能性を指摘している.

9) $\operatorname{Rau}(1974,19 f$.$) は当箇$ は次の通り (単位は $\left.\mathrm{W} \cdot \mathrm{m}^{-1} \cdot \mathrm{K}^{-1},{ }^{\circ} \mathrm{C}\right)$. 金 : 300, 1000, 銀 : 428, 961, 鉄 : 76, 1538, 銅：400, 1084. Cf. 田中良平他（1990, 90f., 274, 289).

11）溶解された状態になる ことを指す. Gotō $(2002,40)$ は, AVŚ XI 10,12;13 や MS II 4,3 等に言及される vájram sec 「vajra を注ぐ」という表現について，「特定の形に鋳造すること」では無く，「鍛造に先立 
ち，精製され，溶解された原材料を金敷に注ぐ」ことを意味すると指摘する.

12) Cf. $P W$ VII, sp. 1286 (s.v. sthā): “7) bestehen (Gegens. vergehen, zu Grunde gehen).” dat. + sthā (act./mid.) については, Delbrück $(1888,143)$ も参照.

13) AVŚ I 16; XII 2 AVP

I 10; XVII 30; 31; 35 14） Cf. Amano (2009, 532). 15) Cf. EWAia II, 494f.「雌馬 (Stute)」. sísa- が宦官と関連付けられる点に特に着目すれば, 繁殖力の無い一代雑種であ る「騾馬」を特に指す可能性も考えられようか. 16）他には ŚBM V 1,2,14 等. Rau （1971, 23f.）は，VSM XIX,80 等の記述が ŚBM XII 7,2,10 における交易の記述に先立つも のと指摘する．交易品としての鉛の利用は恐らく黒 $\mathrm{YS}^{\mathrm{m}}$ まで遡る.

\section{〈参考文献〉}

Amano, Kyoko. 2009. Maitrāyaṇi Samihitā I-II: Übersetzung der Prosapartien mit Kommentar zur Lexik und Syntax der älteren vedischen Prosa. Bremen: Hempen.

Bodewitz, Henk. 1976. The Daily Evening and Morning Offering (Agnihotra) according to the Brāhmaṇas. Leiden: Brill.

Delbrück, Bertold. 1888. Altindische Syntax. Halle an der Saale: Verlag der Buchhandlung des Waisenhauses.

Gotō, Toshifumi. 2002. "Funktionen des Akkusativs und Rektionsarten des Verbums—anhand des Altindoarischen-." In Indogermanische Syntax —Fragen und Perspektiven —, herausgegeben von Heinrich Hettrich unter Mitarbeit von Jeong-Soo Kim, 21-42. Wiesbaden: Ludwig Reichert.

後藤敏文 2004 「人類と死の起源—リグヴェーダ創造讃歌 X 72 —」『仏教文化学会十 周年 北条賢三博士古稀記念論集』山喜房佛書林, 415-432.

Gotō, Toshifumi. 2007. Rig-Veda: Das heilige Wissen. Aus dem vedischen Sanskrit übersetzt und herausgegeben von Michael Witzel und Toshifumi Gotō; unter Mitarbeit von Eijirō Dōyama und Mislav Ježić. Frankfurt am Mein: Verlag der Weltreligionen. (WG-RVI)

Kuiper, Franciscus Bernardus Jacobus. 1991. Aryans in the Rigveda. Amsterdam: Rodopi.

Kulikov, Leonid. 2012. The Vedic -ya-presents: Passives and Intransitivity in Old Indo-Aryan. Amsterdam: Rodopi.

Mittwede, Martin, 1989. Textkritische Bemerkungen zur Kāṭaka-Saṃhitā. Alt- und neu-indische Studien 37. Stuttgart: Franz Steiner Verlag.

Rau, Wilhelm. 1971. Weben und Flechten im vedischen Indien. Mainz: Verlag der Akademie der Wissenschaften und der Literatur.

—.1974. Metalle und Metallgeräte im vedischen Indien. Mainz: Verlag der Akademie der

Wissenschaften und der Literatur.

田中良平他編 1990 『金属材料の事典』朝倉書店.

〈キーワード〉 ヴェーダ文献, 金属, áyas-, lohá-, trapú-, sísa-, 鉄, 銅

(大阪大学非常勤講師, 文学博士) 